\title{
Towards a Critical Theory of Philippine Society ${ }^{1}$
}

Ranilo B. Hermida

\begin{abstract}
The end of philosophy does not really mean its complete dissolution; instead, it means putting an end to the old ways of doing philosophy. Philosophy should not remain the same given the pluralism and diversity of modern society; it cannot hope to explain complex social issues by relying solely on its own methods and resources. Habermas declares that philosophy must be critical theoryits main task the forging of a theory of society aimed at emancipation. This paper elaborates his proposal on how philosophy can serve the goal of critical theory through his analysis of the potency and function of language as communicative action. Using his proposal as framework this paper then reflects on the study and teaching of philosophy in the Philippines and how these may be aligned with the new way of doing philosophy as critical theory.
\end{abstract}

Keywords: Habermas, critical theory, Philippine society, emancipatory philosophy

\section{Introduction}

7 he philosopher is often taken to task about his role in society, and the inclusion of philosophy in our courses is challenged in terms of its relevance to the present. This was never the case in the earlier times when the philosopher was revered as the man of wisdom and he enjoyed his place in society as an esteemed teacher and even royal adviser. However, the current state of misgiving towards philosophy-which extends to the whole of the humanities - is not an entirely new development. The end of philosophy

1 This paper was originally delivered as a keynote lecture during the first Kritike conference with the theme, "Critical Theory at the Margins," held at the Martyrs' Hall of the Ecclesiastical Faculties of the University of Santo Tomas last 1-2 December 2017. The event was organized by the Department of Philosophy of the University of Santo Tomas.

(C) 2019 Ranilo B. Hermida

https://www.kritike.org/journal/special issue/hermida april2019.pdf

ISSN 1908-7330 
had been proclaimed matter-of-factly by some of the most significant thinkers at different periods in history.

In his book, Philosophical-Political Profiles, Jürgen Habermas inquires whether philosophy is still possible and necessary:

... [T] he unsettling question remains whether, after the downfall of systematic philosophy and now even the retreat of philosophy itself, it is still possible to do philosophy, and, if it is, for what purpose philosophy is needed. Why should not philosophy, like art and religion, fall victim to the world-historical process of rationalization described in historical terms by Max Weber and expressed conceptually by Horkheimer and Adorno in their dialectic? Why should not even philosophy itself fade away in the graveyard of a spirit that can no longer affirm and realize itself as absolute? Does philosophy still have a purpose today, and will it tomorrow?2

There are twofold factors that may be cited as the bases for the contention that philosophy has come to an end or has lost its aim. The first is the predominance of capitalism and the materialism engendered in its wake. In this state of affairs, the value of everything is measured in terms of the economic gains it can generate; in light of this evaluation, philosophy is thereby deemed wanting insofar as it is reckoned to serve no utilitarian purpose. The second is the more insidious challenge because it goes to the heart of philosophy as an enterprise of rationality. Habermas calls it "scientism" which he defines as the tendency of positivism to regard the methods of the natural sciences as the only legitimate form of meaningful inquiry. ${ }^{3}$

The emphasis on materialist over other values is corollary to orthodox Marxist theory of the evolution of society and proceeds from its fundamental tenet that law, religion, morality, and the whole sociocultural suprastructure are merely derivatives of the economic mode of production. ${ }^{4}$ Habermas rejected this view as a misreading of history and asserted "the opposite view that the 'normative structures' of culture, morality, and

2 Jürgen Habermas, Philosophical-Political Profiles, trans. by Frederick Lawrence (Cambridge, MA: The MIT Press, 1983), 9.

${ }^{3}$ Jürgen Habermas, Knowledge and Human Interests, trans. by Jeremy J. Shapiro (Boston: Beacon Press, 1971), 4.

${ }^{4}$ Andrew Edgar, The Philosophy of Habermas (Chesham: Acumen Publishing Limited, 2005), 56.

(c) 2019 Ranilo B. Hermida

https://www.kritike.org/journal/special issue/hermida april2019.pdf

ISSN 1908-7330

(cc) BY-NC-ND 


\section{TOWARDS A CRITICAL THEORY OF PHILIPPINE SOCIETY}

collective identity do not simply follow economic or system imperatives and that they evolve according to their own logic." 5

Habermas elaborates his rejoinder to scientism in his first major work, Knowledge and Human Interests, which he developed into a "systematic history of ideas with a practical intention." 6 And the intention is, precisely, "to show how positivism has mutilated our reason and swallowed it whole into a limited theory and practice of science." 7 It is imperative for Habermas, therefore, that we recuperate a more comprehensive concept of reason and disavow the limited understanding to which it had been consigned "as if only empirical or scientific validity claims about factual states of affairs can be rationally contested and redeemed." 8

At the same time, however, Habermas declares that as philosophy "confronts a modern social reality that has itself undergone dramatic and irreversible developments toward complexity, pluralism and diversity," it cannot remain the same inasmuch as "these developments place strong limits on what philosophy can legitimately aspire to explain." 9 Philosophy as theorized and practiced previously has to be recast. This is the real meaning of the end of philosophy: the clearing of a new path towards a way of thinking that is more competent and appropriate to modern social existence. The end of philosophy is, therefore, not a cause for disquiet and alarm, but a source of excitement and interest.

Habermas refashions philosophy after the conception of knowledge inspired by German idealism according to which knowledge is to be at the service of human autonomy. Philosophy, as an enterprise of reason, is rational to the degree that it liberates humanity from the tutelage it has imposed upon itself. Philosophy is to be "knowledge grounded in the emancipatory interest"; ${ }^{10}$ its project is the forging of "a theory of society ... with a practical intention." 11 This new face and task of philosophy is critical theory.

\footnotetext{
${ }^{5}$ Michael Pusey, Jürgen Habermas (London: Routledge, 1993), 40.

${ }^{6}$ Habermas, Knowledge and Human Interests, 4.

${ }^{7}$ Pusey, Jürgen Habermas, 20.

${ }^{8}$ Franklin Gamwell, "Metaphysics and the Rationalization of Society," Process Studies,

${ }^{9}$ Max Pensky, "Historical and Intellectual Contexts," in Jürgen Habermas: Key Concepts, ed. by Barbara Fultner (New York: Routledge, 2011), 30.

${ }^{10}$ Edgar, The Philosophy of Habermas, 88.

${ }^{11}$ Jürgen Habermas, Theory and Practice, trans. by John Viertel (Boston: Beacon Press,
} 23:3-4 (Fall/Winter 1994), 220. 1976), 1.

(c) 2019 Ranilo B. Hermida

https://www.kritike.org/journal/special issue/hermida_april2019.pdf

ISSN 1908-7330

(c) $)$ BY-NC-ND 


\section{Critical Theory: Origins and Directions}

The term "critical theory" was first used in reference to the social scientific research program conducted at the Institute for Social Research by thinkers from widely divergent fields of thought to present a new interpretation of Marxist theory, focusing their speculation on issues and problems that were rarely tackled by more orthodox approaches to Marxism. The orientation of the Institute was initially provided by Max Horkheimer (1895-1973) who was the director in its incipient years. It came to be known later as simply and famously the Frankfurt School, because it was at Frankfurt University in Germany where the Institute was established in 1923 with funds provided by a wealthy industrialist named Felix Weil (1898-1975). Some of the researchers initially associated with critical theory included Theodor Adorno (1903-1969), Erich Fromm (1900-1980), Leo Lowenthal (1900-1993), Herbert Marcuse (1898-1979), and Friedrich Pollock (1894-1970), plus a few others. $^{12}$

The general objective of the School was to revitalize Marxist analysis and to engage in research that is socially scientific and simultaneously oriented towards human emancipation. The approach was to be interdisciplinary: "philosophers, sociologists, economists, legal scholars and even students of psychiatry and literature" collaborated "on large-scale studies of the sources and structure of contemporary social pathologies." 13 Philosophical analysis was coupled with empirical social research "with the goal of critically identifying and indicting sources of injustice, domination and oppression." 14 The social research program of Jürgen Habermas and also the moral philosophical work of Axel Honneth are further developments of critical theory.

What further distinguished the school were the essential features it assigned to critical theory. Critical theory is reflective as differentiated from the natural science theory which it reckoned as objectifying. Critical theory is cognitive in character as it aims towards enlightening individuals so as to clearly determine what their true interests are. Critical theory is emancipatory because it suggests a process through which human agents can liberate themselves from a form of coercion that is self-imposed, being the result of their self-frustration over conscious human action. Raymond Geuss recapitulates these features of the Frankfurt School in the following:

All the members ... are agreed that ... critical theory must be knowledge and must show ideological beliefs

\footnotetext{
12 Pusey, Jürgen Habermas, 32.

${ }^{13}$ Pensky, "Historical and Intellectual Contexts," 19.

${ }^{14}$ Ibid.
} 


\section{TOWARDS A CRITICAL THEORY OF PHILIPPINE SOCIETY}

and attitude to be false. Otherwise ... critical theory could not have its proper emancipatory effect, which depends on its ability to make those who adopt it able to withstand the pressure of the legitimatory apparatus of society. Critical theories must be 'true' because the legitimizing ideologies of the society claim to be 'true.' 15

Moreover, there is one essential element of critical theory that is a common orientation among all its adherents and practitioners: critical theory necessarily entails the critique of ideology - understood in the negative sense and used as label for worldviews that exclusively reflect the particularistic interests of dominant social groups and yet are presented as universally valid or true. Habermas is emphatic of ideology critique; for him, philosophy, particularly as critical theory, is a normative undertaking - "the ideal of critical theory, after all, is to provide a critical diagnosis of the times, which is to say, a diagnosis from a normative standpoint from which how things could be better becomes visible." 16 Critical theorists together maintain that the unveiling of the exclusivist interests behind ideologies "serves to empower social agents to enact social change." 17

\section{From Cognitive Interests to Communicative Action}

Habermas has always assigned to the philosopher the role of being the guardian of reason. He claims that the problem of rationality is ever the central question in every philosophical discussion. Although he is critical of the modernist appropriation of rationality in a restrictedly positivist and instrumentalist manner, Habermas is secure in "the capacity of reason to establish valid standards and to tackle the challenging dilemmas of human life." $18 \mathrm{He}$ concurs with the postulate that rationality is the fundamental principle behind social change. It is, therefore, the abiding task of the philosopher to identify the evolving patterns by which rationality is appropriated in the course of history and to analyze how such appropriation has either advanced or hindered the progress of society. Habermas is confident that this quest will indicate rational grounds for social hope.

\footnotetext{
${ }^{15}$ Raymond Geuss, The Idea of a Critical Theory: Habermas and the Frankfurt School (Cambridge: Cambridge University Press, 1981), 94.

16 Barbara Fultner, "Introduction," in Jürgen Habermas: Key Concepts ed. by Barbara Fultner (New York: Routledge, 2011), 8.

17 Darrell Arnold, "Critical Theory," in International Encyclopedia of the Social $\mathcal{E}$ Behavioral Sciences, ed. by James D. Wright, 2nd ed., Vol. 5 (Waltham, MA: Elsevier, 2015), 293.

${ }^{18}$ Ranilo B. Hermida, Imagining Modern Democracy: A Habermasian Assessment of the Philippine Experiment (Albany: State University of New York Press, 2014), 18.

(c) 2019 Ranilo B. Hermida

https://www.kritike.org/journal/special issue/hermida april2019.pdf

ISSN 1908-7330

(c) BY-NC-ND
} 
The rejection of positivism is centered on its claim of an objective knowledge that is devoid of human interests. Habermas rejects that claim based on the finding by American pragmatism that all forms of knowledge are laden with interest. He exposes the "presence of an unacknowledged connection between knowledge and interest" in the sciences; he suspects that the objectivist claim is an offshoot of "the ontological illusion of pure theory" which the sciences still cling to. ${ }^{19}$ There is no pure theory, however, since there are no theoretical propositions which are unrelated to empirical variables. Habermas declares that once the connection is grasped "the objectivist illusion dissolves and makes visible a knowledge-constitutive interest." ${ }^{20} \mathrm{He}$ identifies three distinct interests: the interest in instrumental control, in understanding, and in emancipation.

There are three categories of processes of inquiry for which a specific connection between the logicalmethodological rules and the knowledge-constitutive interests can be demonstrated. This demonstration is the task of a critical philosophy of science that escapes the snares of positivism. The approach of the empiricalanalytic sciences incorporates a technical cognitive interest; that of the historical-hermeneutic sciences incorporates a practical one; and the approach of critically oriented sciences incorporates the emancipatory interest .... ${ }^{21}$

The cognitive interest that constitutes a realm of knowledge also serves as the underlying factor in the development of the various sciences: the interest in technical or instrumental control in relation to the natural sciences; the interest in understanding to the human sciences; and the interest in emancipation to moralpractical knowledge. ${ }^{22}$ Habermas admits that both the empirical-analytic and the historical-hermeneutic sciences contribute to some form of emancipation from the oppressive conditions of nature and culture, respectively; however, in the process, they perpetuate new oppressive conditions and other pathologies.

Habermas employed his theory of knowledge and human interests in overturning the illusion of pure theory. He then shifted into a theory of language in his critical theory. This shift is what is known as the linguistic turn in his thinking. His theory of language was first formulated as a doctrine of

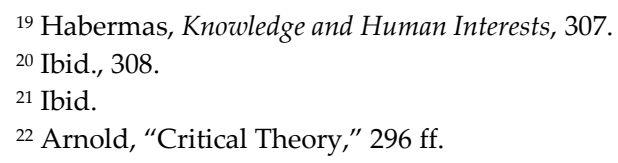




\section{TOWARDS A CRITICAL THEORY OF PHILIPPINE SOCIETY}

dialogue without coercion and later on, presented as universal pragmaticsthe name Habermas proposed for his "research program aimed at reconstructing the universal validity basis of speech." 23

The linguistic turn by way of universal pragmatics may seem to be a puzzling and unwarranted detour in the critical theory of Habermas. The connection between the formal conditions of rational discourse and the emancipatory orientation of critical theory is not easily grasped. It becomes clear, however, when we realize that for Habermas "all forms of prejudice, self-deception, and error" that "significantly thwart the emancipatory potential of the persons or groups so affected" are "appropriated in the selfformative process of an individual or group" which is facilitated by language. ${ }^{24}$ The goal of insuring the autonomy of human agents is blocked by constraints that are rooted in language. Universal pragmatics provides the methodological framework whereby the said constraints are revealed and can thus be contested.

Universal pragmatics focuses on the pragmatic context of language. Communication is not a purely linguistic exercise. Speech is also an action. This concept of speech-acts was adopted by Habermas from the work of Austin and Searle. ${ }^{25}$ A linguistic utterance has a performative componentwhich is to say that when a speaker says something, he is simultaneously doing something, namely, entering into a certain relation with his hearer: "The essential notion operative in universal pragmatics ... is that there are no speech acts without dialogical participants; that is, speech is not possible without, at the very least, a speaker and a hearer engaged in the process of communication." ${ }^{26}$ Communication is coming to an understanding through the medium of language and it involves at once two levels: one, "the level of propositional content which is communicated"; two, "the level of intersubjectivity on which speaker and hearer, through illocutionary acts, establish the relations that permit them to come to an understanding with one another." 27

Habermas rejected the modernist prejudice of equating and limiting the function of reason in social life to instrumental or strategic rationality. Not all social actions can be typified as oriented towards success - "defined as the appearance in the world of a desired state, which can, in a given situation, be

23 Jürgen Habermas, Communication and the Evolution of Society, trans. by Thomas McCarthy (Boston, MA: Beacon Press, 1979), 5.

24 Robert P. Badillo, The Emancipative Theory of Jürgen Habermas and Metaphysics (Washington: The Council for Research in Values and Philosophy, 1991), 55.

${ }^{25}$ Thomas McCarthy, The Critical Theory of Jürgen Habermas (Cambridge, MA: The MIT Press, 1991), 275.

${ }^{26}$ Badillo, The Emancipative Theory of Jürgen Habermas and Metaphysics, 57.

${ }^{27}$ Habermas, Communication and the Evolution of Society, 42.

(c) 2019 Ranilo B. Hermida

https://www.kritike.org/journal/special issue/hermida april2019.pdf

ISSN 1908-7330

(cc) BY-NC-ND 
causally produced through goal-oriented action or omission" 28 - otherwise, we will have to accuse all actors engaging in social action of being calculative and manipulative, treating one another as mere conditions or means to their respective ends, either through enticement or intimidation. Habermas finds "such an underhanded mode of interaction" incapable "to account for how the social fabric is able to hold society together steadfastly." 29

There is another category of rational-purposive action. Habermas designates it as communicative action. The identification of this category is part of his project to rehabilitate the idea of rationality in what he considers the unfinished project of modernity. Communicative action is the orientation towards coming to an understanding between speaker and hearer. Communicative actors act differently from calculative actors in so far as they subordinate their individual goals to their desire to reach a common understanding with other social actors. Habermas writes:

Reaching understanding is ... a process of reaching agreement among speaking and acting subjects ... an agreement that meets the conditions of rationally motivated assent to the content of an utterance ... has a rational basis .... Agreement can indeed be objectively obtained by force; but what comes to pass manifestly through outside influence or the use of violence cannot count subjectively as agreement. Agreement rests on convictions. ${ }^{30}$

The agreement is based on a claim that a speaker proposes to the hearer who may either accept or reject the claim. The basis for the reaction to the claim of the speaker is the evaluation by the hearer based on the presence or absence within the claim of rational grounds. There is, at all times, a sense of rationality embedded in every communicative action. Habermas posits, moreover, an interconnection between knowledge and rationality: the rationality of an utterance is a function of the reliability of the knowledge it contains; hence, every validity claim set forth in communicative action is always criticizable, liable to error, open to objective judgment, and is dependent on a discursive ground to validate it. Utterances are not immediately rational. ${ }^{31}$ Habermas explains why this is so:

\footnotetext{
${ }^{28}$ Jürgen Habermas, The Theory of Communicative Action I, trans. Thomas McCarthy (Boston: Beacon Press, 1984), 285.

${ }^{29}$ Hermida, Imagining Modern Democracy, 20.

${ }^{30}$ Habermas, The Theory of Communicative Action I, 286-87.

${ }^{31}$ Hermida, Imagining Modern Democracy, 21-22.
} 


\section{TOWARDS A CRITICAL THEORY OF PHILIPPINE SOCIETY}

In contexts of communicative action, we call someone rational not only if he is able to put forward an assertion and, when criticized, to provide grounds for it by pointing to appropriate evidence, but also if he is following an established norm and is able when criticized, to justify his action by explicating the given situation in light of legitimate expectations. We even call someone rational if he makes known a desire or an intention, expresses a feeling or a mood, shares a secret, confesses a deed, etc., and is then able to reassure critics in regard to the revealed experience by drawing practical consequences from it and behaving consistently thereafter. ${ }^{32}$

There are three validity claims that a speaker may possibly raise when he attempts to reach understanding with his hearer. The first is truth (Warheit): he claims that the propositional content or existential presupposition of his speech act is true. The second is normative legitimacy or rightness (Richtigkeit): he claims that his statement is correct within the given context. The third is authenticity or truthfulness (Wahrhaftigkeit): he claims that his pronouncement is a sincere expression of his interiority.

When a speaker is able to persuade his hearer that the claim he makes is rational and deserves to be recognized, there can arise a rationally motivated consensus that may serve to coordinate future action. It should be borne in mind, moreover, that the process of coming to an understanding that both speaker and hearer mutually engage in cannot be attained in a situation where they regard each other as strategic adversaries bent on pushing a private agenda to achieve personal objectives. Habermas stresses that precisely "the goal of coming to an understanding is to bring about an agreement that terminates in the intersubjective mutuality of reciprocal understanding, shared knowledge, mutual trust, and accord with one another." 33 This means that both speaker and hearer must consider each other as partners equally intent on the accomplishment of a common goal.

Communicative action seeks the cooperation of dialogical participants through a consensus regarding the rational validity of the norms whereby they understand the situation. The consensus is important because it serves to regulate the otherwise conflicting

\footnotetext{
${ }^{32}$ Habermas, The Theory of Communicative Action I, 15.

${ }^{33}$ Habermas, Communication and the Evolution of Society, 3.
} 
individual interests and to coordinate social action. It also makes possible the rationalization of social action according to the agreed norms in such wise that when the action fails to conform to these norms, an outright criticism can be mounted against it. ${ }^{34}$

In ordinary conversations, these claims may be taken for granted, and yet they are assumed all the time so that the speaker could vindicate his claim if the hearer so demands. It is a presupposition that is shared by communicatively interacting subjects. Universal pragmatics further examines the relation to reality that the speaker establishes in his every utterance. There are three realms of reality to which an utterance may refer: the first is external reality or the world of external nature, of perceived and potentially manipulable objects; the second is normative reality or our world of society or of socially recognized expectations, values, rules; and, the third is inner reality or my world of internal nature, the arena of intentions. Habermas speaks of the reference to the various realms of reality as a process of demarcation:

The universality of the validity claims inherent in the structure of speech can perhaps be elucidated with reference to the systematic place of language. Language is the medium through which speakers and hearers realize fundamental demarcations. The subject demarcates himself: (1) from an environment that he objectifies in the third-person attitude of an observer; (2) from an environment that he conforms to or deviates from in the ego-alter attitude of a participant; (3) from his own subjectivity that he expresses or conceals in a first-person attitude....$^{35}$

These demarcations are accompanied by a basic attitude on the part of the speaker: an objectivating attitude with respect to external nature; a conformative attitude vis-à-vis society; and, an expressive attitude with regard to internal nature. Three parallel modes of communication correspond, respectively, to these attitudes: the cognitive, the interactive, and the expressive. And in each of these modes, there is a specific function that speech performs, namely: the representation of facts for the cognitive; the establishment of legitimate

${ }^{34}$ Hermida, Imagining Modern Democracy, 23.

${ }^{35}$ Habermas, Communication and the Evolution of Society, 66. 


\section{TOWARDS A CRITICAL THEORY OF PHILIPPINE SOCIETY}

interpersonal or social relations for the interactive; and, the disclosure of the speaker's subjectivity.

Unlike an ordinary sentence of which intelligibility depends on its being grammatical, that is to say, its conformity to an established system of recognized rules for the use of language, the three validity claims mentioned above require something more beyond language in order to be intelligible:

... [T] he validity of the propositional content of an utterance depends ... on whether the proposition stated represents a fact (or whether the existential presuppositions of a mentioned propositional content hold); the validity of an intention expressed depends on whether it corresponds to what is actually intended by the speaker; and the validity of utterance performed depends on whether his action conforms to a recognized normative background. Whereas a grammatical sentence fulfills the claim to comprehensibility, a successful utterance must satisfy three additional validity claims: it must count as true for the participants insofar as it represents something in the world, it must count as truthful insofar as it expresses something intended by the speaker; it must count as right insofar as it conforms to socially recognized expectations. ${ }^{36}$

A fundamental question that needs to be answered is about the source of the illocutionary force of an utterance; in other words, how coming to understanding is attained or how the speaker is able to persuade the hearer to enter into an intersubjective relationship through communication. Habermas answers this question by asserting that the hearer can be rationally motivated to accept the content proposed by the speaker. Every communicative action contains the immanent obligation to redeem the validity claim it makes.

The correlation between communicative action and linguistic validity claims denotes the singular capacity of communication to serve as a medium to bind actors in dialogical interaction and to coordinate their action. The binding character of communicative action is embodied in the obligation of the speaker to produce rationally convincing justifications of his or her claims for the sake

${ }^{36}$ Ibid., 28.

(c) 2019 Ranilo B. Hermida

https://www.kritike.org/journal/special issue/hermida april2019.pdf

ISSN 1908-7330

(c) BY-NC-ND 
of his or her hearers, who are bidden to evaluate the claims presented. The raising of a validity claim affirms, moreover, the mutual commitment of participants in discourse to criteria of validity that make communication possible. ${ }^{37}$

The satisfaction of the obligation to redeem a validity claim is according to the mode of communicative action embedded in each claim. In the cognitive mode, the speaker has to supply a ground for the propositional content; in the interactive mode, he has to provide a justification for the normative background; and in the expressive mode, he has to offer a confirmation of his intention. The obligation can be satisfied immediately or mediately. It is satisfied immediately through recourse to experiential certainty with respect to the truth claim; through indicating a corresponding normative background with respect to the rightness claim; through affirmation of what is evident to oneself with respect to the truthfulness claim. The mediate satisfaction of the immanent obligation requires a different process but still according the mode of communication engaged in. David Held explicates the process involved in each of the three modes:

In the cognitive use of language, if an initial statement is found unconvincing, the truth claim can be tested in a theoretical discourse. In the interactive use of language, if the rightness of an utterance is doubted, it can become the subject of a practical discourse. In the expressive use of language, if the truthfulness or sincerity of an utterance is questioned, it can be checked against future action. ${ }^{38}$

Universal pragmatics demonstrates the comprehensive possibility to examine an utterance. This possibility is an essential component of the rational motivation behind the illocutionary force of a speech action. Habermas exclaims:

We can examine every utterance to see whether it is true or untrue, justified or unjustified, truthful or untruthful, because in a speech, no matter what the emphasis, grammatical sentences are embedded in relations to reality in such a way that in an acceptable speech action

\footnotetext{
${ }^{37}$ Hermida, Imagining Modern Democracy, 25.

38 David Held, Introduction to Critical Theory: Horkheimer to Habermas (Berkeley: University of California Press, 1980), 338.
} 


\section{TOWARDS A CRITICAL THEORY OF PHILIPPINE SOCIETY}

segments of external nature, society, and internal nature always come into appearance together. ${ }^{39}$

When a validity claim is proffered and it is accepted, a consensus may be reached. The consensus, however, may not be genuine and the discourse itself may be systematically distorted. Habermas admits that problematic situations may arise but he maintains that these can be overcome by ensuring that the discourse rests on the suspension of the constraints of action. No form of compulsion is tolerated other than the force of the better argument, and only one motive is allowed to dominate and that is the cooperative search for truth. The absence of constraints facilitates the formation of a social relationship among communicative actors insofar as their mutual commitment enables each to see his or her own perspective side by side that of another in relation to the world that they intersubjectively share. Habermas refers to this condition as the ideal speech situation that serves to engender genuine consensus: "a situation in which there is mutual understanding between participants, equal chances to select and employ speech acts, recognition of the legitimacy of each to participate in the dialogue as 'an autonomous and equal partner' where the resulting consensus is due simply 'to the force of the better argument."' 40

The standards for redeeming a validity claim to which the communicative actors commit themselves form the basis of the social bond. The degree of rationalization that informs society and its processes is, according to Habermas, directly proportional to the development of communicative practices in that society. Where these practices are hampered by purposive rationality, "the consequence is that relations which should be based on personal commitment, common understanding and involvement, are instead regulated on an impersonal basis, with alienation, disintegration of social responsibility and decline of legitimacy as results." 41

Universal pragmatics is more than just about the fundamental norms of rational speech. It is an emancipatory science as it points to a larger vision of society-a society where the reign of truth, freedom, and justice can flourish through the inherent structure of social action and language. Habermas argues that truth and virtue, facts and values, theory and practice are inseparable because "the truth of statements is linked in the last analysis to the intention of the good and true life." ${ }^{42}$ The overarching point of his critical theory is that our interest in emancipation impels us to initiate or promote efforts towards building more humane societies by advocating a

\footnotetext{
${ }^{39}$ Habermas, Communication and the Evolution of Society, 68.

${ }^{40}$ Held, Introduction to Critical Theory: Horkheimer to Habermas, 343.

${ }^{41}$ Jarle Weigard and Erik Eriksen, Understanding Habermas: Communicative Action and Deliberative Democracy (London: Continuum, 2003), 6.

${ }^{42}$ Habermas, Knowledge and Human Interests, 317.

(c) 2019 Ranilo B. Hermida

https://www.kritike.org/journal/special_issue/hermida_april2019.pdf

ISSN 1908-7330
}

(c) BY-NC-ND 
rigorous analysis of the complex relationships between espoused ideals and social structures.

It is imperative that we imagine visions which take us beyond our present condition, otherwise, we will simply accede to our present condition and accept it as inevitable. "Without utopian thinking, the given social order may be unduly elevated to the status of the natural order, and so be regarded as unalterable." ${ }^{43}$ Towards the avoidance of this eventuality, Habermas trains his critical theory and expects the philosopher to address his project of thinking and action towards the same end.

\section{Preamble to a Critical Theory of Philippine Society}

One implication of critical theory is the revision of the way philosophy is to be conceived and practiced. Habermas suggests some kind of demotion for philosophy. "Philosophy must be gently but firmly knocked off its pedestal as a discipline with a special claim to transcendent, foundational truth, and assigned a more humble but more socially significant role, one that was tailored specifically to the values and challenges of a secular, 'postmetaphysical,' democratic society." 44 Modern society has developed immensely to an extent that overtaxes the capacity of philosophy to explain using only its distinct concepts and characteristic frameworks. Philosophy has to abandon its entitlement to clarify exclusively the foundation of all knowledge. Instead, it has to cooperate with the empirical sciences in explicating structures of worldviews and forms of life. This is what critical theory demands in our doing philosophy in the context of the social realities obtaining in our country.

Habermas narrates that he was just a teenager during the Nuremberg Tribunal, and was shocked that some of his fellow Germans "instead of being struck by the ghastliness, began to dispute the justice of the trial, procedural questions, and questions of jurisdiction." 45 Max Pensky writes how Habermas was dismayed "that philosophy in post-war Germany could carry on business as usual, as though the period between 1933 and 1945 could simply be bracketed out of consideration." $46 \mathrm{He}$ was scandalized "that the

\footnotetext{
43 James Rurak, "The Imaginative Power of Utopias: A Hermeneutic for Its Recovery," Philosophy \& Social Criticism, 8:2 (Summer 1981), 186.

${ }^{44}$ Pensky, "Historical and Intellectual Contexts," 17.

45 Ibid.

${ }^{46}$ Ibid., 16. “During his university studies at Bonn and Göttingen from 1949 to 1954, Habermas had two major experiences of disillusionment. The first was a crushing realization concerning Martin Heidegger (1889-1976). It was a great shock for him to discover that the philosopher he so admired had written in 1935 of the '... inner truth and greatness of the Nazi movement.' The discovery came when Heidegger republished his 1935 lectures on metaphysics in 1953 without retraction of the astonishing passage. Instead, he appended an explanatory note
} 


\section{TOWARDS A CRITICAL THEORY OF PHILIPPINE SOCIETY}

very idea that philosophy must transform itself in response to the German disaster met with deep resistance." 47

On our part, we must seriously reflect on the study and teaching of philosophy in our country. Our interrogation should factor in the historical upheavals that our country has undergone in the last three decades: the two successful People Power Revolutions of 1986 and 2001 that ousted from the presidency a dictator and a scoundrel, respectively, as well as the third poor people power revolution that began as a protest against the arrest of the scoundrel but later on surfaced the neglect of the social question in the first two manifestly political revolutions. We have to rethink the new curriculum for the undergraduate philosophy program mandated by the Commission on Higher Education beyond the addition of more courses.

Critical theory is a movement of collaboration with the other disciplines - in a "substantive and productive reciprocal dialogue with the newer, adjacent disciplines that it had traditionally held at arm's length." 48 While thinkers who were trained primarily as philosophers initiated this movement, critical theory is not an attempt to sustain the position of philosophy as primum inter pares (first among equals) with the other sciences serving ancillary functions; instead, critical theory situates philosophy as unum inter pares (one among equals). The hierarchical arrangement of the sciences is foresworn and the objective is for the various disciplines to fit with one another in "relations of supplementing and reciprocally presupposing." 49

In still a good number of universities in our country, philosophy is a separate and independent department. It is a service department catering to all the other schools or colleges. In some institutions there is a philosophy department in every college. It is apropos to inquire how much interdisciplinary collaboration does philosophy endeavor to establish with the other disciplines. It would not be a surprise if the philosophy department is hardly in dialogue with the particular school or college it is lodged in. It may just be structurally situated in, but not communicatively engaged with, the school or college it belongs to. Is the philosophy department in the College of Education, for instance, more oriented towards a critical theory of the educational system? Or is the philosophy department of the School of

that the 'greatness' denoted 'the encounter between global technology and modern man.' .... As he recalled much later, 'Then I saw that Heidegger, in whose philosophy I had been living, had given this lecture in 1935 and published it without a word of explanation-that's what really disturbed me.' His second great shock was the discovery of the Nazi past of both of his dissertation supervisors in philosophy at the University of Bonn, Erich Rothacker (1888-1965) and Oskar Becker (1889-1964)." Matthew G. Specter, Habermas: An Intellectual Biography (New York: Cambridge University Press, 2010), 10.

47 Pensky, “Historical and Intellectual Contexts," 16.

${ }^{48}$ Ibid.

${ }^{49}$ Held, Introduction to Critical Theory: Horkheimer to Habermas, 339-340.

(c) 2019 Ranilo B. Hermida

https://www.kritike.org/journal/special issue/hermida april2019.pdf

ISSN 1908-7330

(cc) BY-NC-ND 
Economics involved in research and analysis of how the steering media of money and the profit motive of business foist oppression and inequity in society?

Critical theorists link theory and practice "both noting the effects of social practices on theory formation and formulating theory with a view to emancipating the marginalized."50 Theories are developed neither in a vacuum or from the lofty heights of an ivory tower nor from the comfort of an office armchair. They are woven from the experience of actively engaging with society, wrestling with social issues, being immersed in the crucible of events and even conflicts as the occasion demands. This is how Habermas developed his theories. In one of his interviews, he stated, “... [T] he rhythm of my personal development intersected with the great historical events of the time." ${ }^{51}$ His major works were responses to historical incidents and current social debates:

The Structural Transformation of the Public Sphere (1962) ... evolved from a question of praxis ... how to respond to the multifaceted crisis of the Social Democratic Party after its electoral defeat in 1957 .... The Theory of Communicative Action (1981) ... responded to a pervasive discourse on "technocracy," or rule by experts, in which all political tendencies in West German society from the far left to the conservative right participated .... Between Facts and Norms (1992) ... shows how the work subtly reflects the hopes raised by German reunification and the disillusionment experienced in its wake. ${ }^{52}$

The importance of linking theory to practice can be further appreciated by examining the mutual functionality they serve each other. Theory formation provides a reference, a prototype, or a criterion for the scrutiny of existing conditions. The testing of the theory validates or falsifies it. The value of a theory is proportional to its relevance to the reality it seeks to reflect on and ameliorate. ${ }^{53}$

The unmasking of cognitive interests points not only to the possibility but indeed to the necessity of emancipation "for the history of science, technology and communication is also the history of political

\footnotetext{
${ }^{50}$ Arnold, "Critical Theory," 294.

${ }^{51}$ Peter Dews, Autonomy and Solidarity: Interviews with Jürgen Habermas (London: Verso,

52 Specter, Habermas: An Intellectual Biography, 23-25.

${ }^{53}$ Hermida, Imagining Modern Democracy, 7.
} 1987), 73. 


\section{TOWARDS A CRITICAL THEORY OF PHILIPPINE SOCIETY}

domination and ideological distortion." ${ }^{54}$ Our interest in emancipation, and more so, our striving towards that goal, is an obligation borne of our being philosophers. We are philosophers; we are guardians of rationality. Habermas challenges us to review and update our "vision of the proper tasks and scope of philosophizing" which should proceed from an overarching or metaphilosophical view of our "own times, intellectual landscape, historical situation and social demands ... making [our] relationship with [our] own times the center, rather than the by-product, of the activity of philosophy itself." 55

Critical theorists are public intellectuals. Habermas is "a public intellectual par excellence, contributing on a regular basis to the editorial pages of major newspapers and engaging in public dialogue with other major figures ranging from Jacques Derrida, Michel Foucault and Richard Rorty to then Cardinal Ratzinger, now Pope [Emeritus] Benedict XVI." 56 Of his involvements in numerous current discussions, Stephen Bronner writes:

Habermas has become an exemplary public intellectual. He has taken a position on the major issues of the time: calling for more democracy in the educational system, dealing with student protests, confronting those conservatives who considered it time to wash their hands of the Nazi past in the Historikerstreit, challenging the postmodernist advocates of relativism and experientialism, championing the contributions of the welfare state, opposing the deployment of nuclear missiles in Germany. ${ }^{57}$

Critical theory must specify where and how it may be actualized in practice. We are not the only saviors of our society, but we are also its saviors. We have to delineate clearly and strictly our role considering our status and limits as academics. The primary locus of our intervention is the classroom. Outside the confines of the classroom, the public sphere awaits us, the arena opened up in modern society distinct from the state and the economy - "a site for the production and circulation of discourse that can in principle be critical of the state ... a theater for debating and deliberating rather than for buying and

\footnotetext{
${ }^{54}$ Edgar, The Philosophy of Habermas, 89.

${ }^{55}$ Pensky, "Historical and Intellectual Contexts," 15.

${ }^{56}$ Fultner, "Introduction," in Jürgen Habermas: Key Concepts, 1.

${ }^{57}$ Stephen E. Bronner, Of Critical Theory and Its Theorists (Oxford: Blackwell, 1994), 283.
} 
selling." 58 In the public sphere, the ordinary citizens can "exercise their rational agency by participating in informal discourses on matters of shared interest." 59 From the public sphere, therefore, a movement can emerge that can "give voice to social problems, make broad demands, articulate public interests or needs, and thus attempt to influence the political process more from normative points of view than from the standpoint of particular interests." 60

The prospect of the public sphere is often frustrated, unfortunately, by the dominance of "state bureaucracies and market economies" which results in "squeezing shut the narrow public space between state and market economy, transforming active citizens into passive clients and economic consumers." 61 What we can do in this regard is to support "specific, and focused, analyses of the concrete 'sites' of irrationality" 62 or we can conduct the research and analysis ourselves. For this enterprise, we need to expand our knowledge and supplement our skills with applied research tools and techniques.

We can also join social movements which can "serve as potential carriers of emancipatory social and political change." 63 Habermas cautions us, however, to be discriminating in our choice of social movements: there are "movements with emancipatory potentials and those that remain limited by their orientation towards resistance and withdrawal as such." 64 The old ways of "exposing and opposing" the state that had proved successful in the past are no longer relevant and effective within a political system, where the processes and institutions available for direct participation require of civil society groups the skills of "composing and proposing" policy and governance alternatives. ${ }^{65}$

That seems to be the case with many civil society groups and nongovernment organizations in our country up until now. Marlon Wui and Glenda Lopez explain why this is so:

${ }^{58}$ Nancy Fraser, "Rethinking the Public Sphere: A Contribution to the Critique of Actually Existing Democracy," in Habermas and the Public Sphere, ed. by Craig Calhoun (Cambridge, MA: The MIT Press, 1992), 110.

${ }^{59}$ Pensky, "Historical and Intellectual Contexts," 23.

${ }^{60}$ Jürgen Habermas, Between Facts and Norms: Contributions to a Discourse Theory of Law and Democracy, trans. by William Rehg (Cambridge: The MIT Press, 1996), 355.

${ }^{61}$ Ibid.

62 Pusey, Jürgen Habermas, 35.

${ }^{63}$ Keith Haysom, "Civil Society and Social Movements," in Jürgen Habermas: Key Concepts, ed. by Barbara Fultner (New York: Routledge, 2011), 177.

${ }^{64}$ Ibid., 184.

${ }^{65}$ Hermida, Imagining Modern Democracy, 166. 


\section{TOWARDS A CRITICAL THEORY OF PHILIPPINE SOCIETY}

[S]ocial and political movements, which, in the moment of revolution or transformation, were able to act as powerful catalysts or change-agents, often found themselves lost in the process of the ensuing transition. Armed with skills designed more to oppose or confront-than create or negotiate-policy and governance, these change-advocates, who were also potential participants in the new status quo, discovered themselves at a disadvantage vis-à-vis comebacking technocrats and politicians more adept in the so-called rules of the game. ${ }^{66}$

This is one window of opportunity open to us where we can make a meaningful contribution. We can help enhance the political efficacy of the leaders and members of social movements in the country, we can assist them in acquiring "the necessary understanding of state dynamics and processes and the tools for carrying out its multiple functions as critique, conscience, partner, or opponent, as the case may be, of the state ...." ${ }^{67}$ We can also lend our competence "in adjudicating the depth of insights and in analyzing the validity of arguments" 68 that are proposed by the state and other interest groups for the understanding of ordinary people in our society. In this way, we can hasten and heighten the process of rationalization for them to be able to engage in meaningful communicative interaction on issues that affect them.

\section{Conclusion}

The above proposal is inchoate, and it is offered as a preamble to future efforts towards the forging of a critical theory of Philippine societyan endeavor worth pursuing both as a matter of research interest and a demand of our current social conditions. Critical theory calls for a new understanding of the role of philosophy and the task of philosophers: "for Habermas the intellectual life is not a game, or a career, or a cultivation of wit and taste, or even 'learning for learning's sake.' It is above all a vocation ... to

${ }^{66}$ Marlon A. Wui and Ma. Glenda S. Lopez, "State-Civil Society Relations in PolicyMaking," in Philippine Democracy Agenda 2: State-Civil Society Relations in Policy-Making, ed. by Marlon A. Wui and Ma. Glenda S. Lopez (Quezon City: Third World Studies Center, 1997), 1.

${ }^{67}$ Ibid.

68 Rainier Ibana, "The Democratic Aspirations of Civil Society and Habermas' Discourse Theory of Morality," in Philosophy, Culture, and Education, ed. by Philip Cam et al. (Seoul: Korean National Commission for UNESCO, 1999), 47.

(c) 2019 Ranilo B. Hermida

https://www.kritike.org/journal/special issue/hermida april2019.pdf

ISSN 1908-7330

(c) BY-NC-ND 
anticipate and to justify a better world society-one that affords greater opportunities for happiness, peace, and community." 69

Critical theory reinvents philosophy as a socially committed and interdisciplinary enterprise of rationality - feasible only through "a specific ongoing relationship with parallel disciplines in the natural and above all in the social sciences." 70 It signals the end of philosophy as many of us perhaps have known it. This conference charts, therefore, a new direction for doing philosophy in our country: it is an act of subversion, a breaching of old traditions. It is a call to transcend the present, to a renewal that is as necessary as it is possible.

Department of Philosophy, Ateneo de Manila University, Philippines

\section{References}

Arnold, Darrell, "Critical Theory," in International Encyclopedia of the Social \& Behavioral Sciences, ed. by James D. Wright, 2nd ed., Vol. 5 (Waltham, MA: Elsevier, 2015).

Badillo, Robert P., The Emancipative Theory of Jürgen Habermas and Metaphysics (Washington: The Council for Research in Values and Philosophy, 1991).

Bronner, Stephen E., Of Critical Theory and Its Theorists (Oxford: Blackwell, 1994).

Dews, Peter, Autonomy and Solidarity: Interviews with Jürgen Habermas (London: Verso, 1987).

Edgar, Andrew, The Philosophy of Habermas (Chesham: Acumen Publishing Limited, 2005).

Fraser, Nancy, "Rethinking the Public Sphere: A Contribution to the Critique of Actually Existing Democracy," in Habermas and the Public Sphere, ed. by Craig Calhoun (Cambridge, MA: The MIT Press, 1992).

Fultner, Barbara, "Introduction," in Jürgen Habermas: Key Concepts ed. by Barbara Fultner (New York: Routledge, 2011).

Gamwell, Franklin, "Metaphysics and the Rationalization of Society," Process Studies, 23:3-4 (Fall/Winter 1994).

Geuss, Raymond, The Idea of a Critical Theory: Habermas and the Frankfurt School (Cambridge: Cambridge University Press, 1981).

Habermas, Jürgen, Between Facts and Norms: Contributions to a Discourse Theory of Law and Democracy, trans. by William Rehg (Cambridge: The MIT Press, 1996).

${ }^{69}$ Pusey, Jürgen Habermas, 14.

${ }^{70}$ Pensky, "Historical and Intellectual Contexts," 19.

(c) 2019 Ranilo B. Hermida https://www.kritike.org/journal/special issue/hermida_april2019.pdf ISSN 1908-7330 


\section{TOWARDS A CRITICAL THEORY OF PHILIPPINE SOCIETY}

Communication and the Evolution of Society, trans. by Thomas McCarthy (Boston, MA: Beacon Press, 1979). Knowledge and Human Interests, trans. by Jeremy J. Shapiro (Boston: Beacon Press, 1971). Philosophical-Political Profiles, trans. by Frederick Lawrence (Cambridge, MA: The MIT Press, 1983).

The Theory of Communicative Action I, trans. Thomas McCarthy (Boston: Beacon Press, 1984). Theory and Practice, trans. by John Viertel (Boston: Beacon Press, 1976).

Haysom, Keith, "Civil Society and Social Movements," in Jürgen Habermas: Key Concepts, ed. by Barbara Fultner (New York: Routledge, 2011).

Held, David, Introduction to Critical Theory: Horkheimer to Habermas (Berkeley: University of California Press, 1980).

Hermida, Ranilo B., Imagining Modern Democracy: A Habermasian Assessment of the Philippine Experiment (Albany: State University of New York Press, 2014).

Ibana, Rainier, "The Democratic Aspirations of Civil Society and Habermas' Discourse Theory of Morality," in Philosophy, Culture, and Education, ed. by Philip Cam et al. (Seoul: Korean National Commission for UNESCO, 1999).

McCarthy, Thomas, The Critical Theory of Jürgen Habermas (Cambridge, MA: The MIT Press, 1991).

Pensky, Max, "Historical and Intellectual Contexts," in Jürgen Habermas: Key Concepts, ed. by Barbara Fultner (New York: Routledge, 2011).

Pusey, Michael, Jürgen Habermas (London: Routledge, 1993).

Rurak, James, "The Imaginative Power of Utopias: A Hermeneutic for Its Recovery," Philosophy \& Social Criticism, 8:2 (Summer 1981).

Specter, Matthew G., Habermas: An Intellectual Biography (New York: Cambridge University Press, 2010).

Wui, Marlon A. and Ma. Glenda S. Lopez, "State-Civil Society Relations in Policy-Making," in Philippine Democracy Agenda 2: State-Civil Society Relations in Policy-Making, ed. by Marlon A. Wui and Ma. Glenda S. Lopez (Quezon City: Third World Studies Center, 1997).

Weigard, Jake and Erik Eriksen, Understanding Habermas: Communicative Action and Deliberative Democracy (London: Continuum, 2003).

(c) 2019 Ranilo B. Hermida https://www.kritike.org/journal/special issue/hermida april2019.pdf ISSN 1908-7330

(c) BY-NC-ND 